\title{
The Egyptian Red Crescent Society is 75 years old (II) *
}

\section{Egyptian Red Crescent Youth Activities}

Taking part in community-service activities is a natural way for young people to satisfy their aspirations and enables them to shoulder their responsibilities as future citizens.

This is why the Egyptian Red Crescent has always endeavoured to make use of young people's abilities, help them to become part of society, show them how they can accomplish useful work for the community and, in so doing, support the International Red Cross and Red Crescent Movement.

In 1938 the Society's Administrative Board decided to set up Red Crescent youth groups in schools and universities so that, should the need arise, a reserve of volunteers would be available.

In 1945 the Egyptian Red Crescent Youth Association was founded to help attain the humanitarian objectives of the Red Crescent and Red Cross Societies around the world.

Since then, the Egyptian Red Crescent Youth has been active both in time of war and in time of peace.

\section{(a) In time of war:}

The Egyptian Red Crescent Youth played a prominent role during the wars of 1956, 1967 and 1973 by working in hospitals, collecting blood for war victims and providing civil defence and other useful public services.

\section{(b) In time of peace:}

The Red Crescent Youth does work in the medical field, particularly health education and vaccination campaigns and blood collection. It

\footnotetext{
* See $I R R C$, No. 260, pp. 541-545.
} 
organizes first-aid and health-care courses to prepare for natural disasters and epidemics.

In the social field it takes part in the fight against overpopulation and illiteracy; it assists social institutions, in particular, day-care centres and homes and clubs for children and the elderly. It contributes to local development by carrying out social studies on individual communities and providing other services such as organizing Red Crescent Youth camps.

The Red Crescent Youth feels it very important that young people be able to meet each other and has therefore created a series of summer camps for its youth sections at which they take courses, perform public services and enjoy recreational activities.

Young people from the Egyptian Red Crescent and those from the Red Crescent and Red Cross Societies of other countries attend international youth camps such as the one organized each year by the Turkish Red Crescent.

In 1986 the Egyptian Red Crescent organized an International Red Crescent and Red Cross Youth camp.

Exchanges and visits - The Egyptian Red Crescent promotes exchanges between the Red Crescent Youth of Egypt and those of other Red Crescent and Red Cross Societies, notably the German Red Cross in the Federal Republic of Germany, the Spanish Red Cross and the Turkish Red Crescent.

Cultural symposia - The Egyptian Red Crescent has organized a series of cultural symposia to discuss youth-related topics, for example finding and organizing activities for young volunteers in all areas of the Society's work, support for the Movement and the role of youth in promoting peace throughout the world.

\section{Social work performed by the Egyptian Red Crescent}

Social welfare is one of the Egyptian Red Crescent's major areas of endeavour. It works to promote the protection of families, children, the elderly and the disabled, and contributes to community development. Its principal achievements are listed below.

1. Protecting children: 55 day-care centres which can accommodate up to 5,500 children, and 5 Red Crescent clubs which can receive almost 600 children per year.

2. Protecting the elderly: There is a Red Crescent house in Alexandria which accommodates 120 old people per year, and two clubs, one in Ismailia and one in Minya, for 200 old people per year.

3. Protecting young people: 17 social and educational clubs with almost 1,600 members. 
4. Protecting women: The Red Crescent has opened 13 sewing, tapestry and knitting shops for some 450 women and girls.

In the Governorate of Menufiya there is a hostel for foreign women which every year houses 60 female students who come from distant regions. Another hostel in the Governorate of Sharqiya has been built for 100 foreign female students and employees.

5. Welfare: Two Red Crescent welfare offices-one in the Governorate of Alexandria and the other in Ismailia - each year provide aid for hundreds of people in distress.

6. Family reunification: The Egyptian Red Crescent has begun to do tracing work aimed at bringing together family members who have lost contact with each other.

\section{Egyptian Red Crescent training and research activities}

In order to augment the sophisticated techniques used by the National Society in planning and research and to improve the training necessary to perform the Society's work, the Administrative Board of the Egyptian Red Crescent decided on 7 July 1986 to set up a Red Crescent training and research centre to aid in planning its programmes and training its volunteers and employees. The centre's first project was writing the history of the Egyptian Red Crescent Society from its creation in 1912 to the present day. It has also published a Red Crescent training handbook.

\section{The Egyptian Red Crescent's work to promote peace in the world}

The Egyptian Red Crescent has always supported efforts to bring about disarmament and peace and indeed it has been a very active member of the Commission on the Red Cross, Red Crescent and Peace since that Commission was set up.

Whenever our Society attends a national, regional or international conference or symposium, it makes a point of appealing for an end to all forms of torture and terrorism.

It co-operates with other Red Crescent and Red Cross Societies in countries affected by conflict and violence and aids them in performing their humanitarian work. 


\section{The dissemination of international humanitarian law by the Egyptian Red Crescent}

The Egyptian Red Crescent has set up a programme to disseminate knowledge of international humanitarian law. It has translated the four Geneva Conventions into Arabic and those texts have been published and distributed free of charge to all Arab National Societies and groups and individuals concerned with international humanitarian law. In conjunction with the Egyptian Society of International Law, it also organized two conferences in which other Arab countries and Red Crescent volunteers took part. A seminar on international humanitarian law is also planned for late 1987 or early 1988.

\section{Information activities of the Egyptian Red Crescent}

The Egyptian Red Crescent uses several forms of publicity: the Egyptian Red Crescent Review (a quarterly, social and cultural periodical), Red Crescent books and bulletins on the history of the Red Crescent, "Ten questions and answers on the Red Cross and Red Crescent" and "The Red Crescent in the field".

\section{Conclusion}

As can be seen from the above, the Egyptian Red Crescent in its early days limited itself to medical and relief work but has gradually widened its activities to include social welfare. Thanks to its membership of the League of Red Cross and Red Crescent Societies and its relations with the ICRC, especially since 1949 , the Society has been able to help spread knowledge of the Geneva Conventions and ensure that their provisions are implemented. It has also developed close relations with National Societies around the world, becoming a champion of the humanitarian spirit in time of peace as well as in time of war.

Yahia Hassan Darwish Secretary General 